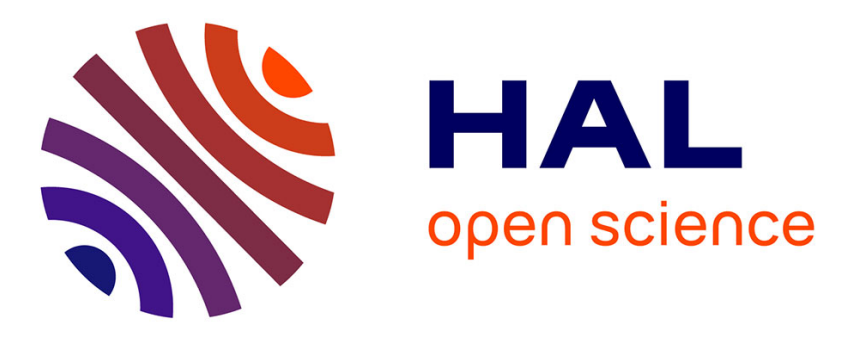

\title{
Interferon gamma response to Mycobacterium avium subsp. paratuberculosis specific lipopentapeptide antigen L5P in cattle
}

\author{
Sébastien Holbert, Maxime Branger, Armel Souriau, Bérénice Lamoureux, \\ Christelle Ganneau, Gaëlle Richard, Thierry Cochard, Christophe Tholoniat, \\ Sylvie Bay, Nathalie Winter, et al.
}

\section{To cite this version:}

Sébastien Holbert, Maxime Branger, Armel Souriau, Bérénice Lamoureux, Christelle Ganneau, et al.. Interferon gamma response to Mycobacterium avium subsp. paratuberculosis specific lipopentapeptide antigen L5P in cattle. Research in Veterinary Science, 2015, 102, pp.118-121. 10.1016/j.rvsc.2015.07.017 . hal-01188322

\section{HAL Id: hal-01188322 \\ https://hal.science/hal-01188322}

Submitted on 28 Aug 2015

HAL is a multi-disciplinary open access archive for the deposit and dissemination of scientific research documents, whether they are published or not. The documents may come from teaching and research institutions in France or abroad, or from public or private research centers.
L'archive ouverte pluridisciplinaire HAL, est destinée au dépôt et à la diffusion de documents scientifiques de niveau recherche, publiés ou non, émanant des établissements d'enseignement et de recherche français ou étrangers, des laboratoires publics ou privés. 


\title{
Interferon gamma response to Mycobacterium avium subsp. paratuberculosis specific lipopentapeptide antigen L5P in cattle
}

\author{
Gaëlle Richard $^{\mathrm{a}}$, Thierry Cochard ${ }^{\mathrm{a}}$, Christophe Tholoniat ${ }^{\mathrm{b}}$, Sylvie Bay ${ }^{\mathrm{c}, \mathrm{d}}$, Nathalie Winter ${ }^{\mathrm{a}}$, \\ Jean Louis Moyen ${ }^{\mathrm{e}}$, Franck Biet ${ }^{\mathrm{a}}$ \\ a UMR1282, Infectiologie et Santé Publique (ISP-311), INRA Centre Val de Loire, F-37380 Nouzilly, France \\ b Groupement de Défense Sanitaire de la Région Centre (GDS Centre), 4 rue Robert Mallet Stevens BP 501, F-36018 Châteauroux, France \\ c Institut Pasteur, Unité de Chimie des Biomolécules, Département de Biologie Structurale et Chimie, 75015 Paris, France \\ d CNRS UMR 3523, 75015 Paris, France \\ e Laboratoire Départemental d'Analyse et de Recherche de Dordogne, 161 av Winston Churchill, 24660 Coulounieix Chamiers, France
}

Sébastien Holbert ${ }^{\mathrm{a}, *}$, Maxime Branger ${ }^{\mathrm{a}}$, Armel Souriau ${ }^{\mathrm{a}}$, Bérénice Lamoureux ${ }^{\mathrm{b}}$, Christelle Ganneau ${ }^{\mathrm{c}, \mathrm{d}}$,

\section{A R T I C L E I N F O}

\section{Article history:}

Received 22 January 2015

Received in revised form 8 July 2015

Accepted 26 July 2015

Available online $\mathrm{xxxx}$

\section{Keywords:}

Mycobacterium avium subsp. paratuberculosis

Paratuberculosis

Johne's disease

Antigen

Lipopeptide

Lipopentapeptide: L5P

IFN- $\gamma$ release assay: IGRA

Cell mediated immune response

\begin{abstract}
A B S T R A C T
After Mycobacterium avium subsp. paratuberculosis (Map) infection the cell-mediated immune (CMI) response indicative of early Th1 activation may be detected using interferon-gamma release assay (IGRA). Currently, the purified protein derivatives (PPDs), i.e., the total extract of mycobacteria antigens are used to recall CMI responses against Map.

This study aimed to assess the ability of the chemically synthesized Map specific cell wall lipopentapeptide L5P to induce CMI response in cows infected by Map compared to PPD. L5P and PPD elicited an IFN- $\gamma$ response in 12 and 35 animals from two Map infected herds respectively, but IFN- $\gamma$ was not detected in the 13 cows recruited from a non-infected herd. Levels of IFN- $\gamma$ detected were higher with PPD than with L5P. There was no correlation between the IFN- $\gamma$ response and the humoral response to Map or faecal culture.
\end{abstract}

(C) 2015 Published by Elsevier Ltd.

\section{Introduction}

Mycobacterium avium subsp. paratuberculosis (Map) is the causative agent of the fatal granulomatous chronic infectious enteritis named Johne's disease (JD) or paratuberculosis. This disease is found worldwide in ruminant farming (Lombard et al., 2013; Nielsen and Toft, 2009).

Map interacts with and manipulates the host immune system. The classical response pattern to mycobacteria infection involves firstly a $\mathrm{T}$ helper (Th) 1 response which then switches to a Th2 response (Stabel, 2000,2006 ). The IFN- $\gamma$ release assay (IGRA) takes advantage of this by assessing the cell mediated immune (CMI) response to purified protein derivatives (PPDs) (Jungersen et al., 2011) or recombinant antigens

\footnotetext{
* Corresponding author.

E-mail addresses: sebastien.holbert@tours.inra.fr (S. Holbert), maxime.branger@tours.inra.fr (M. Branger), a-souriau@orange.fr (A. Souriau), blamoureux@gdma36.fr (B. Lamoureux), christelle.ganneau@pasteur.fr (C. Ganneau), gaelle703@gmail.com (G. Richard), thierry.cochard@tours.inra.fr (T. Cochard), ctholoniat@gdma36.fr (C. Tholoniat), sylvie.bay@pasteur.fr (S. Bay), nathalie.winter@tours.inra.fr (N. Winter), jl.moyen@dordogne.fr (J.L. Moyen), franck.biet@tours.inra.fr (F. Biet).
}

selected for their specificity (Gurung et al., 2014; Hughes et al., 2013; Mikkelsen et al., 2011a). This method requires antigens capable of eliciting a sensitive and specific response, and which are currently under investigation (Mikkelsen et al., 2011b). PPDs elicit a strong response with this method but include crude undefined antigens that are shared with other mycobacterium species and which can crossreact resulting in false-positive results (Bannantine et al., 2002).

In this study a cell wall lipopeptide antigen produced specifically by the Map subspecies: the lipopentapeptide L5P (Biet et al., 2008; Reyrat et al., 2009), was tested to recall CMI responses against Map. Previous studies have shown that L5P is abundant in lipid extracts from Map cells and differs greatly from glycopeptidolipids (GPLs), which are characteristic of the other M. avium complex (Mac) members (Barrow et al., 1995; Ripoll et al., 2007). Unlike GPL, L5P contains a peptide core which is not glycosylated due to the absence of a free hydroxyl group, and the fatty acid in the $N$-terminal domain of the molecule is shorter, saturated and not hydroxylated (Biet et al., 2008). This specific antigen has been synthesized chemically and evaluated in different studies for its potential use in serological assays to detect Map infection (Biet et al., 2008; Costanzo et al., 2012; Eckstein et al., 2006; Thirunavukkarasu et al., 2013; Verdier et al., 2013). 
The present study aimed to assess the ability of chemically synthesized L5P to elicit in vitro CMI responses, by quantifying IFN- $\gamma$ release in whole blood stimulation assays from cows recruited from noninfected, Map infected herds and Mycobacterium bovis infected herds.

\section{Materials and methods}

Animals included in this study were not subjected to any in vivo manipulation prior to stunning for industrial slaughter and therefore, no specific ethics committee authorization was required.

Cattle from three groups from four herds were included in the study. (1) 13 animals from a non-infected herd which tested negative twice for Map antibodies in serum and faecal culture at cow-level (Supplementary file 1). (2) 36 animals randomly recruited from two Map infected herds, herd infection being confirmed by Map culture and elimination of annual clinical cases of paratuberculosis included in the national paratuberculosis surveillance programme: herd (A) of 139 cows with a seroprevalence of $7.2 \%$ and herd (B) of 163 cows with a seroprevalence of 7.2\% (Supplementary files 2 and 3). (3) 27 animals from a herd free of paratuberculosis but included in official eradication campaigns for bovine tuberculosis and subject to the official diagnostic tests for $M$. bovis ( single intradermal test SIT and IFN- $\gamma$ assays). Of the 83 cows analysed from this herd the 27 recruited (32.5\%) were certified $M$. bovis positive based on PCR IS6110 and spoligotyping performed on the strain isolated (Supplementary file 4).

Samples of faeces, serum and blood were collected.

Blood was collected by venipuncture in vacutainer tubes. Heparinized whole blood was used for stimulation and IFN- $\gamma$ response analyses. Approximately $6 \mathrm{~h}$ after sampling, $225 \mu \mathrm{L}$ of whole blood was placed in 96-well plates (Falcon ${ }^{\circledR}$ ) previously loaded with $25 \mu \mathrm{L}$ of RPMI medium $16401 \times$ (Gibco ${ }^{\circledR}$ by Life Technologies ${ }^{\mathrm{TM}}$ ) as Nil antigen and $10 \mu \mathrm{g} / \mathrm{mL}$ of Purified Protein Derivative Avium (PPD-A 2500 Prionics Lelystad BV PPD-A); in addition for animal samples from the non-infected and $M$. bovis infected herds, wells had also been loaded with $10 \mu \mathrm{g} / \mathrm{mL}$ of Purified Protein Derivative Bovis (PPD-B 3000 Prionics Lelystad BV), $5 \mu \mathrm{g} / \mathrm{mL}$ of L5P synthesized chemically as previously described (Biet et al., 2008) and $5 \mu \mathrm{g} / \mathrm{mL}$ of Pokeweed mitogen (PWM) (Sigma-Aldrich) all diluted in RPMI. After stimulating for $24 \mathrm{~h}$ at $37^{\circ} \mathrm{C}$ and $5 \% \mathrm{CO}_{2}$, whole blood was centrifuged at $1500 \mathrm{rpm}$, plasma was collected and frozen for IFN- $\gamma$ cytokine quantification using an ELISA (Bovigam 1G ® Prionics). IFN- $\gamma$ responses were expressed as an $\mathrm{S} / \mathrm{P}$ ratio $(\mathrm{S} / \mathrm{P}$ ratio $=$ Specific Sample OD / Positive control OD - Negative control OD); Specific Sample OD indicates that Nil antigen optical density was taken into account. The cut off value of the IFN- $\gamma$ response to PPD-A, PPD-B and L5P was calculated as the $95 \%$ percentile of response to each antigen in the non-infected herd.

Serology was performed with the IDEXX Map Ab Test (IDEXX Laboratories, Inc.) according to the manufacturer's instructions and the L5P humoral immune response was quantified as described previously (Biet et al., 2008)

Strain isolation and identification were performed with Map chromosomal DNA obtained as described previously (Thibault et al., 2007). All the strains isolated were screened for the Map specific IS900 insertion sequence using synthetic oligonucleotides (Sigma), as described previously (Sanderson et al., 1992). Map isolates were then genotyped by MLVA using the markers, Mycobacterial Interspersed Repetitive Units - Variable Number of Tandem Repeats (MIRU-VNTR), according to Thibault et al., 2007 (Thibault et al., 2007).

IFN- $\gamma$ responses to PPD-A, PPD-B or L5P were compared for cows from the non-infected herd, the four categories of the Map infected herd and the two groups of the M. bovis infected herd using the nonparametric Bonferroni's multiple comparison test. Correlation analysis of IFN- $\gamma$ responses to PPD-A and L5P was estimated with the Spearman's rank correlation for non-parametric correlations (GraphPad Prism version 5, GraphPad Software, La Jolla, CA, USA).

\section{Results and discussion}

The IFN- $\gamma$ responses to chemically synthetized L5P and PPD-A antigen of animals from the non-infected, Map infected and $M$. bovis infected herds are shown in Fig. 1. To complete the data at the time of sampling, IGRA, serology and mycobacterial culture status were determined for each animal (Supplementary files 1, 2, 3, 4). Adult animals were recruited to avoid a response related to immune immaturity.

All animals of the non-infected herd were negative for the humoral immune response to Map antigens and L5P and for mycobacterial culture (Supplementary File 1). IFN- $\gamma$ responses to PPDs and L5P of the non-infected herd were negative and were used to calculate cutoff values. The cut-off value of the IFN- $\gamma$ response to PPD-A, PPD-B and L5P was calculated as the $95 \%$ percentile of response to each antigen in the non-infected herd. Thus, the cut-off values of the IFN- $\gamma$ response to PPD-A, PPD-B and L5P were 0.060, 0.065 and 0.013 (S/P ratio) respectively represented with a dotted line (Fig. 1).

In the Map infected herds (herds A and B), 16 of the 36 animals analysed were positive for the humoral immune response to Map antigens, and nine were positive for Map culture with the same INMV2 genotype. These results were used to define four categories of animals (Fig. 1). Animals which were: 1 ) positive for faecal culture and serology $(\mathrm{FC}+\mathrm{S}+; \mathrm{n}=6), 2$ ) negative for both tests ( $\mathrm{FC}-\mathrm{S}-$; $\mathrm{n}=16), 3$ ) only seropositive ( $\mathrm{FC}-\mathrm{S}+; \mathrm{n}=11)$ and 4 ) only faecal culture positive $(\mathrm{FC}+\mathrm{S}-; \mathrm{n}=3)$. The median IFN- $\gamma$ responses are presented in Fig. 1 and were higher for PPD-A from 0.150 to 0.940 (S/P ratio) compared to the median IFN- $\gamma$ response which was below 0.0165 (S/P ratio) for L5P. According to the cut-off value, 35 of the 36 cows tested IFN- $\gamma$ positive for PPD-A of which 12 also tested positive for L5P. Spearman's rank correlation for IFN- $\gamma$ responses to PPD-A and L5P indicates a significant correlation (alpha $=0.05$ ) with $r=0.6305$. The non-infected herd and all categories of the Map infected herd showed significant $(\mathrm{p}<0.05)$ differences in IFN- $\gamma$ response to PPD-A and L5P (except category $\mathrm{S}-\mathrm{F}+$ ). Animals recruited from the Map infected herds had greater IFN- $\gamma$ responses to PPD-A than the noninfected herd. This would suggest that animals have been exposed to Map, and was confirmed by strain identification in several animals which were subclinically infected. The IFN- $\gamma$ responses to PPD-A were systematically higher than to L5P. As observed previously, a single antigen induced a weaker response than PPD (Gurung et al., 2014; Mikkelsen et al., 2011a). L5P is a lipopeptide, its structure presumably involves specific CD1 antigen presentation to T cells (Young et al., 2009) but its hydrophobicity would imply a non-specific cell membrane affinity which could hamper the expected presentation, thus partly explaining the weak IFN- $\gamma$ response. Furthermore, the small antigenic peptide ( 5 amino acids) represented only a small part of the Map specific antigen (Bannantine and Paustian, 2006). A combination of lipid transport molecules (van den Elzen et al., 2005) and a selected recombinant antigen pool (Mikkelsen et al., 2011a) could enhance the IFN- $\gamma$ response at the same time conserving high specificity. Using an enzyme-linked immunospot (ELISPOT) assay, a highly sensitive technique to detect cytokine release, could be an alternative way to improve response detection (Begg et al., 2009). For the animals used in the present study, the IFN- $\gamma$ responses using PPD-A and L5P did not enable to define a specific status which corresponded to that obtained from the humoral response and faecal culture.

In the $M$. bovis infected herd the humoral immune response to Map antigens and L5P was negative for all animals. M. bovis culture was confirmed for 27 of the 83 animals. When comparing the IFN- $\gamma$ responses induced by L5P (Fig. 1A) PPD-A (Fig. 1B) and PPD-B (Fig. 1C) of cows from the $M$. bovis infected herd, the $27 M$. bovis positive culture cows and the 56 negative culture cows showed significantly $(\mathrm{p}<0.05)$ different IFN- $\gamma$ responses to PPD-B and showed no significant differences in IFN- $\gamma$ responses to L5P and PPD-A confirming $M$. bovis infection. With a currently estimated cut-off value $(0.013 \mathrm{~S} / \mathrm{P}$ ratio) of the IFN- $\gamma$ responses to L5P from the non-infected herd, three cows from the 
A

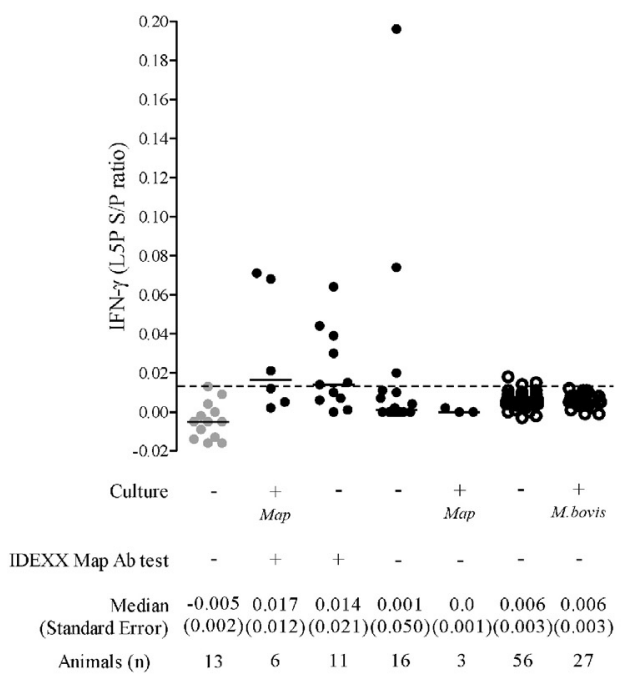

B

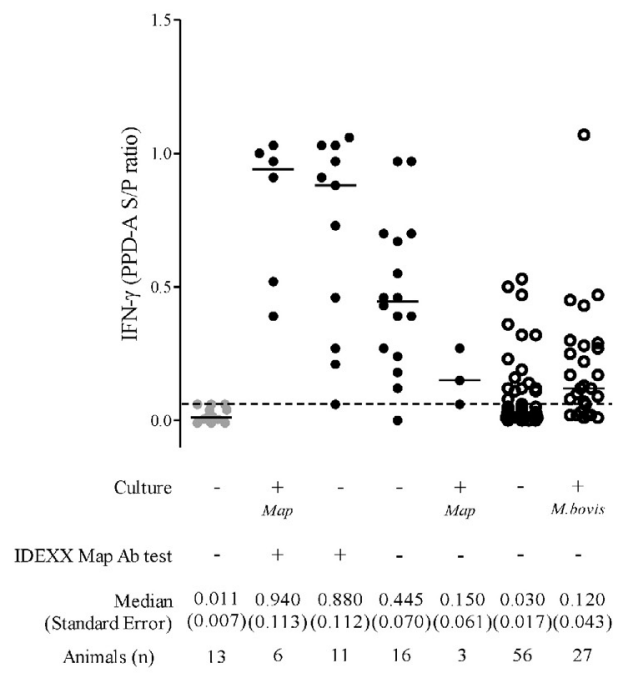

C

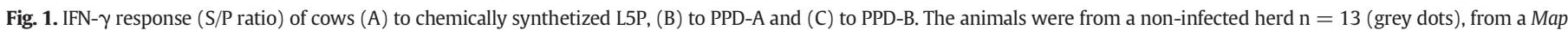

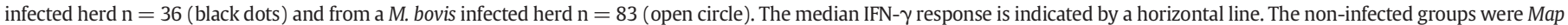

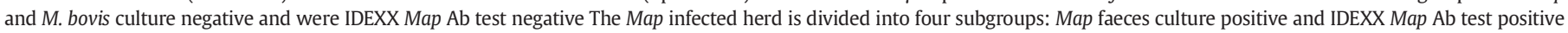

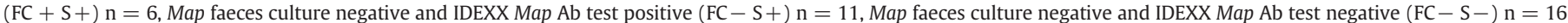

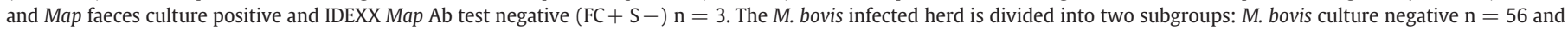

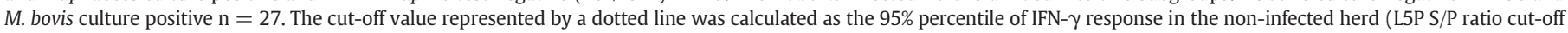

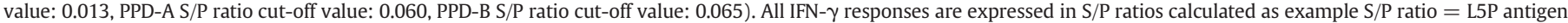
OD - Nil antigen OD / Positive control OD - Negative control OD.

M. bovis culture negative group included in the $M$. bovis exposed herd showed weak responses to L5P (0.018, 0.015 and $0.014 \mathrm{~S} / \mathrm{P}$ ratio).

In conclusion, chemically synthesized L5P can induce CMI responses which can be quantified by assaying IFN- $\gamma$ release in whole blood stimulation. Despite significant differences between the IFN- $\gamma$ response to L5P from the Map infected herds and the other herds, these preliminary results supporting a specific response to L5P need to be confirmed in a larger number of herds which are Map infected, Map/M. bovis coinfected and $M$. bovis infected to validate its specificity and improve the cut-off value. Future longitudinal studies of heifers from Map infected herds would be a good strategy to evaluate the potential of L5P IGRA test considering the immunopathological status of animals not only with regard to JD but also other mycobacterial diseases like bovine tuberculosis.

Supplementary data to this article can be found online at http://dx. doi.org/10.1016/j.rvsc.2015.07.017.

\section{Conflict of interests}

The authors confirm that they have no conflict of interest in relation to this work.

\section{Authors' contributions}

SH carried out the studies, prepared and wrote the manuscript. MB, AS and GR contributed to developing the IGRA methodology, and collecting and analysing the data. BL and CT contributed to JD animal recruitment and discussions. CG and SB synthetized L5P and SB helped write the manuscript. TC identified bacteria and strains. NW contributed to the study design and participated in the discussions. JLM contributed to $M$. bovis infected herd recruitment and IGRA analysis. FB participated in the study design and helped write the manuscript. All authors read and approved the final manuscript.

\section{Acknowledgements}

This study was funded by the "Région Centre" Para3B Project (Convention: 20110068745) and by EMIDA-EraNet Mycobacdiagnosis (Convention: 2011-EMID-005-02). The authors thank breeders for their interest and their involvement in this project.

\section{References}

Bannantine, J.P., Paustian, M.L., 2006. Identification of diagnostic proteins in Mycobacterium avium subspecies paratuberculosis by a whole genome analysis approach. Methods Mol. Biol. 345, 185-196.

Bannantine, J.P., Baechler, E., Zhang, Q., Li, L., Kapur, V., 2002. Genome scale comparison of Mycobacterium avium subsp. paratuberculosis with Mycobacterium avium subsp. avium reveals potential diagnostic sequences. J. Clin. Microbiol. 40, 1303-1310.

Barrow, W.W., Davis, T.L., Wright, E.L., Labrousse, V., Bachelet, M., Rastogi, N., 1995. Immunomodulatory spectrum of lipids associated with Mycobacterium avium serovar 8. Infect. Immun. 63, 126-133.

Begg, D.J., de Silva, K., Bosward, K., Di Fiore, L., Taylor, D.L., Jungersen, G., Whittington, R.J., 2009. Enzyme-linked immunospot: an alternative method for the detection of interferon gamma in Johne's disease. J. Vet. Diagn. Investig. 21, 187-196.

Biet, F., Bay, S., Thibault, V.C., Euphrasie, D., Grayon, M., Ganneau, C., Lanotte, P., Daffe, M., Gokhale, R., Etienne, G., Reyrat, J.M., 2008. Lipopentapeptide induces a strong host humoral response and distinguishes Mycobacterium avium subsp. paratuberculosis from M. avium subsp. avium. Vaccine 26, 257-268.

Costanzo, G., Pinedo, F.A., Mon, M.L., Viale, M., Gil, A., Illia, M.C., Gioffre, A., Arese, A. Traveria, G., Romano, M.I., 2012. Accuracy assessment and screening of a dairy herd with paratuberculosis by three different ELISAs. Vet. Microbiol. 156, 183-188.

Eckstein, T.M., Chandrasekaran, S., Mahapatra, S., McNeil, M.R., Chatterjee, D., Rithner C.D., Ryan, P.W., Belisle, J.T., Inamine, J.M., 2006. A major cell wall lipopeptide of Mycobacterium avium subspecies paratuberculosis. J. Biol. Chem. 281, 5209-5215.

Gurung, R.B., Begg, D.J., Purdie, A.C., de Silva, K., Bannantine, J.P., Whittington, R.J., 2014. Lymphoproliferative and gamma interferon responses to stress-regulated Mycobacterium avium subsp. paratuberculosis recombinant proteins. Clin. Vaccine Immunol. 21, 831-837.

Hughes, V., Denham, S., Bannantine, J.P., Chianini, F., Kerr, K., May, L., McLuckie, J., Nath M., Stevenson, K., 2013. Interferon gamma responses to proteome-determined specific recombinant proteins: potential as diagnostic markers for ovine Johne's disease. Vet. Immunol. Immunopathol. 155, 197-204.

Jungersen, G., Mikkelsen, H., Grell, S.N., 2011. Use of the johnin PPD interferon-gamma assay in control of bovine paratuberculosis. Vet. Immunol. Immunopathol. 148, 48-54.

Lombard, J.E., Gardner, I.A., Jafarzadeh, S.R., Fossler, C.P., Harris, B., Capsel, R.T., Wagner, B.A., Johnson, W.O., 2013. Herd-level prevalence of Mycobacterium avium subsp. 
paratuberculosis infection in United States dairy herds in 2007. Prev. Vet. Med. 108, 234-238.

Mikkelsen, H., Aagaard, C., Nielsen, S.S., Jungersen, G., 2011a. Novel antigens for detection of cell mediated immune responses to Mycobacterium avium subsp. paratuberculosis infection in cattle. Vet. Immunol. Immunopathol. 143, 46-54.

Mikkelsen, H., Aagaard, C., Nielsen, S.S., Jungersen, G., 2011b. Review of Mycobacterium avium subsp. paratuberculosis antigen candidates with diagnostic potential. Vet. Microbiol. 152, 1-20.

Nielsen, S.S., Toft, N., 2009. A review of prevalences of paratuberculosis in farmed animals in Europe. Prev. Vet. Med. 88, 1-14.

Reyrat, J.M., Bay, S., Biet, F., 2009. Synthetic antigenic peptides and lipopeptides derived from Mycobacterium avium subsp. paratuberculosis, Patent WO 2009/053844 A1.

Ripoll, F., Deshayes, C., Pasek, S., Laval, F., Beretti, J.L., Biet, F., Risler, J.L., Daffe, M., Etienne, G., Gaillard, J.L., Reyrat, J.M., 2007. Genomics of glycopeptidolipid biosynthesis in Mycobacterium abscessus and M. chelonae. BMC Genomics 8, 114.

Sanderson, J.D., Moss, M.T., Tizard, M.L., Hermon-Taylor, J., 1992. Mycobacterium paratuberculosis DNA in Crohn's disease tissue. Gut 33, 890-896.

Stabel, J.R., 2000. Transitions in immune responses to Mycobacterium paratuberculosis. Vet. Microbiol. 77, 465-473.

Stabel, J.R., 2006. Host responses to Mycobacterium avium subsp. paratuberculosis: a complex arsenal. Anim. Health Res. Rev. 7, 61-70.
Thibault, V.C., Grayon, M., Boschiroli, M.L., Hubbans, C., Overduin, P., Stevenson, K., Gutierrez, M.C., Supply, P., Biet, F., 2007. New variable-number tandem-repeat markers for typing Mycobacterium avium subsp. paratuberculosis and M. avium strains: comparison with IS900 and IS1245 restriction fragment length polymorphism typing. J. Clin. Microbiol. 45, 2404-2410.

Thirunavukkarasu, S., Plain, K.M., Eckstein, T.M., de Silva, K., Whittington, R.J., 2013. Cellular and humoral immunogenicity of Mycobacterium avium subsp. paratuberculosis specific lipopentapeptide antigens. Res. Vet. Sci. 95, 123-129.

van den Elzen, P., Garg, S., Leon, L., Brigl, M., Leadbetter, E.A., Gumperz, J.E., Dascher, C.C., Cheng, T.Y., Sacks, F.M., Illarionov, P.A., Besra, G.S., Kent, S.C., Moody, D.B., Brenner, M.B., 2005. Apolipoprotein-mediated pathways of lipid antigen presentation. Nature 437, 906-910.

Verdier, J., Deroche, L., Allez, M., Loy, C., Biet, F., Bodier, C.C., Bay, S., Ganneau, C., MatysiakBudnik, T., Reyrat, J.M., Heyman, M., Cerf-Bensussan, N., Ruemmele, F.M., Menard, S., 2013. Specific IgG response against Mycobacterium avium paratuberculosis in children and adults with Crohn's disease. PLoS One 8, e62780.

Young, D.C., Kasmar, A., Moraski, G., Cheng, T.Y., Walz, A.J., Hu, J., Xu, Y., Endres, G.W., Uzieblo, A., Zajonc, D., Costello, C.E., Miller, M.J., Moody, D.B., 2009. Synthesis of dideoxymycobactin antigens presented by $\mathrm{CD} 1$ a reveals $\mathrm{T}$ cell fine specificity for natural lipopeptide structures. J. Biol. Chem. 284, 25087-25096. 